\title{
Molecular markers confirm the presence of the alien snowflake coral Carijoa riisei (Octocorallia: Alcyonacea) in Cabo Verde Islands (Central-East Atlantic).
}

\section{Evandro Pires Lopes ( $\nabla$ elopes@uta.cv )}

Universidade Técnica do Atlântico: Instituto de Engenharias e Ciências do Mar https://orcid.org/00000003-3938-1560

\section{Rui Freitas}

Universidade Técnica do Atlântico: Instituto de engenharias e Ciências do Mar

\section{Raquel Xavier}

Centro de Investigação em Biodiversidade e Recursos Genéticos: Universidade do Porto Centro de Investigacao em Biodiversidade e Recursos Geneticos

\section{João Deus Soares}

Universidade Técnica do Atlântico: Instituto de Engenharias e Ciências do Mar

\section{António M Santos}

Centro de Investigação em Biodiversidade e Recursos Genéticos: Universidade do Porto Centro de Investigacao em Biodiversidade e Recursos Geneticos; Faculdade de Ciências da Universidade do Porto

\section{Research Article}

Keywords: alien species, Octocorallia, Carijoa riisei, Eastern Atlantic

Posted Date: May 7th, 2021

DOI: https://doi.org/10.21203/rs.3.rs-366544/v1

License: (c) (i) This work is licensed under a Creative Commons Attribution 4.0 International License. Read Full License 


\section{Abstract}

The snowflake coral Carijoa riisei is one of the most invasive and successfully adapting species in the coastal marine environment. This species can disperse through ballast waters or fouling on the hull of ships, which allows it to expand very quickly to areas where it is not native. Recently $C$. riisei was identified in the Porto Grande Bay in São Vicente island in Cabo Verde Islands. We analysed mitochondrial and nuclear DNA sequences from specimens collected at this locality to determine the potential origin of this invasion. Lack of genetic variation in both mitochondrial and nuclear genes suggest a very recent invasion (bottleneck effect) but did not permit to establish its origin with total confidence.

\section{Introduction}

Carijoa riisei (Duchassaing and Michelotti, 1860) is a colonial octocoral (Alcyonacea: Clavulariidae) characterised by bright orange colour, and commonly known as snowflake coral. The species was described from the US Virgin Islands as Clavularia riisei Duchassaing and Michelotti, 1860 (incorrectly spelt in the original publication as " $C$. rusei") and later considered native from the Caribbean and Western tropical Atlantic, ranging from Florida to Brazil (Bayer, 1961; Kahng et al., 2008). However, recent molecular analyses of specimens collected around the globe have shown that instead $C$. riisei is most likely native to the Indo-Pacific region and that only recently it has spread into the Atlantic and the eastern Pacific (Concepcion et al., 2010).

A genetic-based approach to determine the origin of the snowflake corals introduced in the Hawaiian waters indicated that Carijoa is native to the Indo-Pacific Concepcion et al. $(2008,2010)$. Early invaders arrived most likely in the late 1960s at O'ahu Island and the first confirmed records of snowflake corals date from 1972 on the biofouling communities of Pearl Harbor (Jokiel, 2008). On the West African coast, the first record $C$. riisei is an unconfirmed observation from the Sherbro Island in Sierra Leone (Bayer, 1961). More recently, it has been reported for the Gulf of Guinea where it was identified on the Principe Island in 2004 and Santana islet, in the eastern coast of the São Tomé Island, during a National Geographic expedition in 2006 (Concepcion et al., 2010). In 2006 Carijoa sp. was photographed in Senegal, on the Madeleine island, from the mangroves on Saloum, and recently at the Séminole bank at a depth of $27 \mathrm{~m}$ (Patrice de Voize, pers. comm.). In Cabo Verde, the snowflake coral started to be regularly observed on the floating structures previously occupied by sedentary organisms and native corals, coinciding with the building of new marinas and the increased frequency of game fishing boats and yachts docking (E. Lopes, pers. obs.).

Although the archipelago of Cabo Verde has very low primary productivity, it contains a high diversity of marine ecosystems with several endemisms (Almeida et al., 2015). In coastal ecosystems of Cabo Verde, several hard coral species occur forming small clusters (called 'coralline communities') inside shallow or protected warmer bays. This natural habitat fragmentation results in the diversification of some groups of organisms associated with those habitats, as in the case of coastal reef fishes, the endemic Conus 
(Cunha et al., 2014), Fissurela (Cunha et al., 2017) and Euthria gastropods and nudibranchs (Fraussen and Swinnen, 2016).

Recent studies have reported the presence of alien species from the Atlantic West in Cabo Verde, introduced via the North Equatorial counter-current. This current has been suggested to have promoted the introduction of the slipper lobster (Parribacus antarcticus) from the tropical western Atlantic via larval dispersal (Freitas and Wirtz, 2019). This study aims to report and diagnose the presence of highly invasive species $C$. riisei in the Cabo Verde archipelago using molecular tools (nDNA and mtDNA analyses) and identify phylogenetic relationships between Cabo Verde samples and other regions to find a pattern of possible origins and comment on mitigation measures.

\section{Materials And Methods}

\subsection{Study area}

The Porto Grande Bay is a semi-circular basin ( $2 \mathrm{Km}$ mean radius) located on the northwest coast of the São Vicente Island (Cabo Verde), covering an area of $2.43 \mathrm{Km}$ with the maximum depth of 30 meters (Fig. 1). The bay is naturally protected from strong sea currents, which promoted intense port activities over the last two centuries, with a significant increase since the 1950s. Specimens of Carijoa spp. were collected in the bay under the floating structures of the Marina of Mindelo. Additional explorations were carried out in May 2017 in two other places in the bay to detect the presence of the snowflake coral: on the Matiota rocky beach which is near to a desalination plant of the island and at the main dock of Porto Grande. Individuals were photographed, and tissue samples were stored in $96 \%$ ethanol.

\subsection{DNA extraction and sequencing}

DNA was extracted using a salt method adapted from Sambrook and Russell (2000) and sequences were amplified by employing a regular PCR routine. Mitochondrial and nuclear loci were chosen based on the PCR success rate, sequence quality and availability at GenBank. Portions of two mitochondrial genes, NADH dehydrogenase 2 and 6 subunits (ND2 and ND6), and the intron in the 54 kDa subunit of the signal recognition particle (SRP54) nuclear gene were amplified with the primers described by McFadden et al. (2004) and Concepcion et al. (2008), respectively (Supplementary Material, Table 1). All PCRs were performed in reactions of $25 \mu$ containing $1 \mathrm{X}$ of PCR buffer, $2.5 \mathrm{mM}$ of each dNTP, $0.5 \mathrm{mM}$ of each primer, $2.5 \mathrm{mM}$ of $\mathrm{MgCl} 2,2 \mu \mathrm{l}$ of DNA matrix, $0.1 \mu \mathrm{g} / \mu \mathrm{l}$ BSA and $0.3 \mathrm{U}$ of Platinum Taq DNA Polymerase (Invitrogen, Carlsbad, CA). PCR cycles were performed was as follows: one cycle of 5 min at $94^{\circ} \mathrm{C}, 40$ cycles of 45 seconds at $94^{\circ} \mathrm{C}, 1 \mathrm{~min}$ at $52^{\circ} \mathrm{C}$ and $1.30 \mathrm{~min}$ at $72^{\circ} \mathrm{C}$, with the final step of extension of 10 $\min$ at $72^{\circ} \mathrm{C}$.

Sequencing was outsourced to a commercial company (Beckman Coulter). Quality control obtained was performed manually with BioEdit (Hall, 1999) and sequences obtained were compared with those available in GenBank and deposited by Concepcion et al. (2008); Concepcion et al. (2010) and Quintanilla 
et al. (2017) (Suppl. Material Table S1; Suppl. material Table S2; Suppl. material Table S3). All sequences were deposited in GenBank with accession numbers MN200342 and MN200344.

\subsection{Data analysis}

The Blast algorithm (National Center for Biotechnology Information 2018) was used to confirm the taxonomic identity of Carijoa riisei. Mitochondrial DNA sequences were translated into proteins to detect possible pseudogenisation of mitochondrial genes. The final alignments were produced using the ClustcalW algorithm available in BioEdit (Hall, 1999). For the mtDNA, alignments resulted from the concatenation of ND2 and ND6 haplotypes. Non-rooted networks of haplotypes based on the 95\% parsimony were constructed separately for mitochondrial and nuclear markers using TCS1.21 (Clement et al., 2000) with the final manipulation in tcsBU (Santos et al., 2016). For the nDNA data, gaps were treated as a 5th state as in Quintanilla et al. (2017).

\section{Results}

Snowflake coral colonies were found in three out of eight sites surveyed in 2017. In addition to the location of the original occurrence in 2011 (Marina do Mindelo), Carijoa was also spotted in two other locations further North: on the quay of the commercial port and nearby the desalination plant of the island (Fig. 1). In all locations, colonies of considerable size were found covering man-made underwater structures, such as metal pipes and concrete blocks. A total of 18 individuals were collected, six in each site.

Final alignment of mtDNA genes (concatenated ND2-ND6) had a total length of $1152 \mathrm{bp}$, and at least one reading frame was free from stop codons, indicating that sequences were not nuclear copies of mtDNA genes. Final alignment of nuclear gene (SRP54) had a total length of $126 \mathrm{bp}$. No variation was found at nuclear and mitochondrial level with each genetic marker being represented by a unique variant. In the haplotype network (Fig. 2) it can be seen that all samples correspond to allele 8 (A8) of SRP54 and haplotype 18 (H18) of the concatenated ND2-ND6 segment, as described by Concepcion et al. (2010) and Quintanilla et al. (2017).

\section{Discussion}

Genetic data confirmed the identification of Carijoa riisei in São Vicente Island, Cabo Verde, which becomes the northernmost distributional limit in the West African coast, roughly $150 \mathrm{Km}$ North of its previous limit (Dakar, Senegal). From 2011 onward, snowflake corals have colonized new areas in Cabo Verde but remain restricted the area of Porto Grande Bay in the Island of S. Vicente.

Lack of genetic variation in both mitochondrial and nuclear genes is typical of recent colonization involving a reduced number of organisms (bottleneck effect). Unfortunately, this lack of genetic variability also hinders our ability to identify with any degree of confidence the source populations of such recent invasion of Cabo Verde. The A8 allele of the SRP54 nuclear gene is distributed globally, being more 
common in the Atlantic (Concepcion et al., 2008) and in the Pacific coast of Central America (Quintanilla et al., 2017), where its frequency is on average greater than 50\% (except for São Tomé and Príncipe archipelago). For the mitochondrial concatenated genes (ND2-ND6) the haplotype found in Cabo Verde (H18) is fixed in most Atlantic sites with the exception of Porto Rico ( 35\%) and São Tomé e Príncipe archipelago $(>80 \%)$.

The geographic position of Cabo Verde archipelago creates a favourable environment for the introduction of new marine species. The fauna of Cabo Verde has three known main natural origins: the adjacent African continent, the Mediterranean Sea, and the remaining Macaronesian archipelagos (Madeira and Canary Islands) (Morri et al., 2000). The major oceanographic patterns, such as the Canary current (cold current in the eastern border of the Azores anticyclone that connects with the northern trade winds in the latitudes of Cabo Verde archipelago), facilitate the connectivity between these regions, allowing the interchange of the species (López et al., 2019).

Human-mediated transport is a clear possibility in Cabo Verde because the archipelago is part of the international Atlantic shipping hub (Seebens et al., 2013). Coincidentally, or not, the first marina built in the bay of Porto Grande was precisely the location where the snowflake was spotted for the first time, during a regular inspection of floating structures. Present molecular data suggest that the origin of $C$. riisei invasion in Cabo Verde is most likely located in the Atlantic. Nonetheless, one cannot outright exclude an invasion from the Indian or the Pacific oceans, where the $\mathrm{A} 8$ and $\mathrm{H} 18$ variants are also present. Many vessels from these regions operating in the Atlantic use the Mindelo shipyard regularly, which includes long stops for the cleaning of hulls in a dry dock.

The finding of the $C$. riisei in the Cabo Verde archipelago should be considered a major concern, especially since populations seem to be slowly expanding. Since 2011, the frequency and abundance of snowflake coral in the Porto Grande area has increased. Cape Verde could be a jumping-off for the propagation of the species to other archipelagos further north, such as Madeira, Canary Islands or even the Mediterranean Sea. The impact of highly invasive coral species, with fast growth, vegetative propagation, and superior competitive ability for space and food may compromise the pristine habitat quality for the local fauna (Kahng and Grigg, 2005).

The Porto Grande bay has been the major entry point for several alien species from the West Atlantic (Freitas and Castro 2005; Freitas and Wirtz, 2019). For these reasons, management and monitoring of introduced-species by the local maritime authorities should be a regular procedure to facilitate early detection and identify means for the eradication. Other national coastal localities with the similar characteristics are the Palmeira bay (Sal Island) and the Gamboa bay in the capital Praia (Santiago Is.), monitoring programs should be urgently developed to identify the presence/absence of $C$. riisei.

\section{Declarations}

\section{Acknowledgements}


This study was part of the Evandro P. Lopes BIODIV PhD program and was supported by Research Grant for Master in the area of marine biology reference ICETA 2016-31, by the European Regional Development Fund (ERDF) through compete program and by National Funds through FCT - Foundation for Science and Technology (project PTDC/MAR-BIO/0902/2014-POCI-01-0145-FEDER-016550). We thank Nélida VeraCruz (Uni-CV former student) for collecting and share the first specimen from Marina of Mindelo (2011), Dr Peter Wirtz (CCMAR, University of Algarve, Portugal), Dr Samuel Kahng (University of Hawaii. USA), Dr Leen van Ofwegen (Curator of the Museum of Natural History, Netherlands) and Patrice de Voize in Senegal (2011) for valuable suggestions, and they contributions for the first identification process. We also thank Edita Magileviciute for valuable suggestions and corrections to an earlier version of the manuscript. This article is the output of the Portuguese - Cabo Verdean TwinLab, established between $\mathrm{CIBIO} / \operatorname{InBIO}$ and Uni-CV.

\section{Conflict of interest}

The authors declare that they have no conflict of interest.

\section{Contributions}

EL and AMS designed this study. EL collected the samples and did the laboratory work. EL and AMS analyzed data. EL wrote the manuscript and RF, RX, JDS, and AMS revised it. All authors contributed with their ideas and reviewed the final version of the manuscript.

\section{Availability of data and material}

Not applicable

\section{Code availability}

Not applicable

\section{References}

Almeida C, Freitas R, Lopes EP, Melo T, Afonso CML (2015) Biodiversidade Marinha. In: Vasconcelos R, Freitas RM, Hazevoet CJ (eds) História natural das Ilhas Desertas-Santa Luzia, Branco e Raso., Sociedade Caboverdiana de Zoologia, Porto, Portugal, pp 82-118

Bayer FM (1961) The shallow-water Octocorallia of the West Indian region. A manual for marine biologists. Martinus Nijhoff: The Hague, Netherlands 
Clement M, Posada D, Crandall KA (2000) TCS: a computer program to estimate gene genealogies. Mol Ecol 9(10):1657-1659. https://doi.org/10.1046/j.1365-294x.2000.01020.x

Concepcion G, Crepeau M, Wagner D, Kahng S, Toonen R (2008) An alternative to ITS, a hypervariable, single-copy nuclear intron in corals, and its use in detecting cryptic species within the octocoral genus Carijoa. Coral Reefs 27(2):323-336. https://doi.org/10.1007/s00338-007-0323-x

Concepcion G, Kahng S, Crepeau M, Franklin E, Coles S, Toonen R (2010) Resolving natural ranges and marine invasions in a globally distributed octocoral (genus Carijoa). Mar Ecol Prog Ser 401:113-127. https://doi.org/10.3354/meps08364

Cunha RL, Lima FP, Tenorio MJ, Ramos AA, Castilho R, Williams ST (2014) Evolution at a different pace: distinctive phylogenetic patterns of cone snails from two ancient oceanic archipelagos. Syst Biol 63(6):971-987. https://doi.org/10.1093/sysbio/syu059

Cunha RL, Assis JM, Madeira C, Seabra R, Lima FP, Lopes EP, Williams ST, Castilho R (2017) Drivers of Cape Verde archipelagic endemism in keyhole limpets. Sci Rep 7(1):1-11.

https://doi.org/10.1038/srep41817

Fraussen K, Swinnen F (2016) A review of the genus Euthria Gray, 1839 (Gastropoda: Buccinidae) from the Cape Verde Archipelago. Xenophora Taxonomy 11:9-31

Freitas R, Castro M (2005) Occurrence of Panulirus argus (Latreille, 1804) (Decapoda, Palinuridae) in the northwest islands of the Cape Verde archipelago (Central-east Atlantic). Crustaceana 78(10): 1191-1201

Freitas R, Wirtz P (2019) First record of the sculptured mitten lobster Parribacus antarcticus (Crustacea, Decapoda, Scyllaridae) from the Cabo Verde Islands (eastern Atlantic). Arquipelago - Life and Marine Sciences 36:15-18 
Hall TA (1999) Bioedit: a user-friendly biological sequence alignment editor and analysis program for windows 95/98/nt. Nucleic Acids Symposium Series 41, 95-98

Jokiel PL (2008) Biology and ecological functioning of coral reefs in the main hawaiian islands. In: Riegl B.M., Dodge R.E. (eds) Coral Reefs of the USA, Coral Reefs of the World, vol 1. Springer, Dordrecht, pp 489-517,

Kahng SE, Grigg RW (2005) Impact of an alien octocoral, Carijoa riisei, on black corals in Hawaii. Coral Reefs 24(4):556-562. https://doi.org/10.1007/s00338-005-0026-0

Kahng SE, Benayahu Y, Wagner D, Rothe N (2008) Sexual reproduction in the invasive octocoral Carijoa riisei in Hawaii. Bull Mar Sci 82(1):1-17

López C, Reimer JD, Brito A, Simón D, Clemente S, Hernández M (2019) Diversity of zoantharian species and their symbionts from the Macaronesian and Cape Verde ecoregions demonstrates their widespread distribution in the Atlantic Ocean. Coral Reefs 38(2):269-283. https://doi.org/10.1007/s00338-01901773-0

McFadden CS, Tullis ID, Hutchinson MB, Winner K, Sohm JA (2004) Variation in coding (NAGH Dehydrogenase Subunits 2, 3, and 6) and noncoding intergenic spacer regions of the mitochondrial genome in Octocorallia (Cnidaria: Anthozoa). Mar Biotechnol 6(6):516-526. https://doi.org/10.1007/s10126-002-0102-1

Morri C, Cattaeno-Vietti R, Sartoni G, Banchi CN (2000) Shallow epibenthic communities of Ilha do Sal (Cape Verde Archipelago, eastern Atlantic). Arquipelago - Life Marine Sciences Supplement 2 2(A):157165

Quintanilla E, Wilke T, Ramírez-Portilla C, Sarmiento A, Sánchez JA (2017) Taking a detour: invasion of an octocoral into the tropical eastern pacific. Biol Invasions 19(9):2583-2597.

https://doi.org/10.1007/s10530-017-1469-2 
Sambrook J, Russell D (2000) Molecular Cloning, 3-Volume Set: A Laboratory Manual. Cold Spring Harboc Lab Press, New York

Santos AM, Cabezas MP, Tavares Al, Xavier R, Branco M (2016) tcsBU: a tool to extend TCS network layout and visualization. Bioinformatics 32(4):627-628. https://doi.org/10.1093/bioinformatics/btv636

Seebens H, Gastner M, Blasius B, Courchamp F (2013) The risk of marine bioinvasion caused by global shipping. Ecol Lett 16(6):782-790. https://doi.org/10.1111/ele.12111

\section{Table}

Due to technical limitations, Table 1 is only available as a download in the supplementary files section.

\section{Figures}




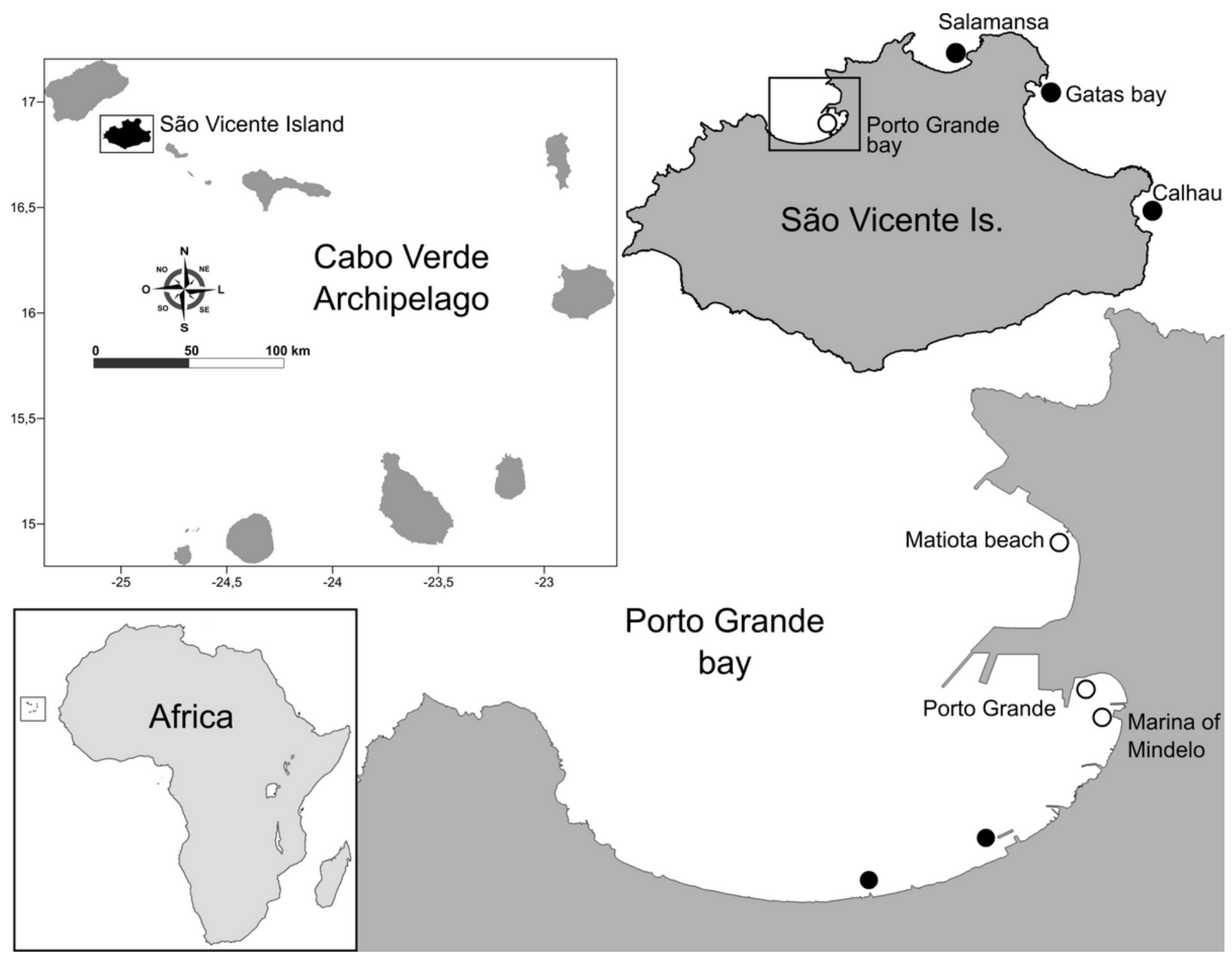

Figure 1

Location of the Cabo Verde archipelago and Porto Grande Bay in the São Vicente island. The location where the presence of the species C. riisei was prospected is presented. Legend: - places where the presence of the species was recorded; - areas where the species was not observed before May 2017. 
A

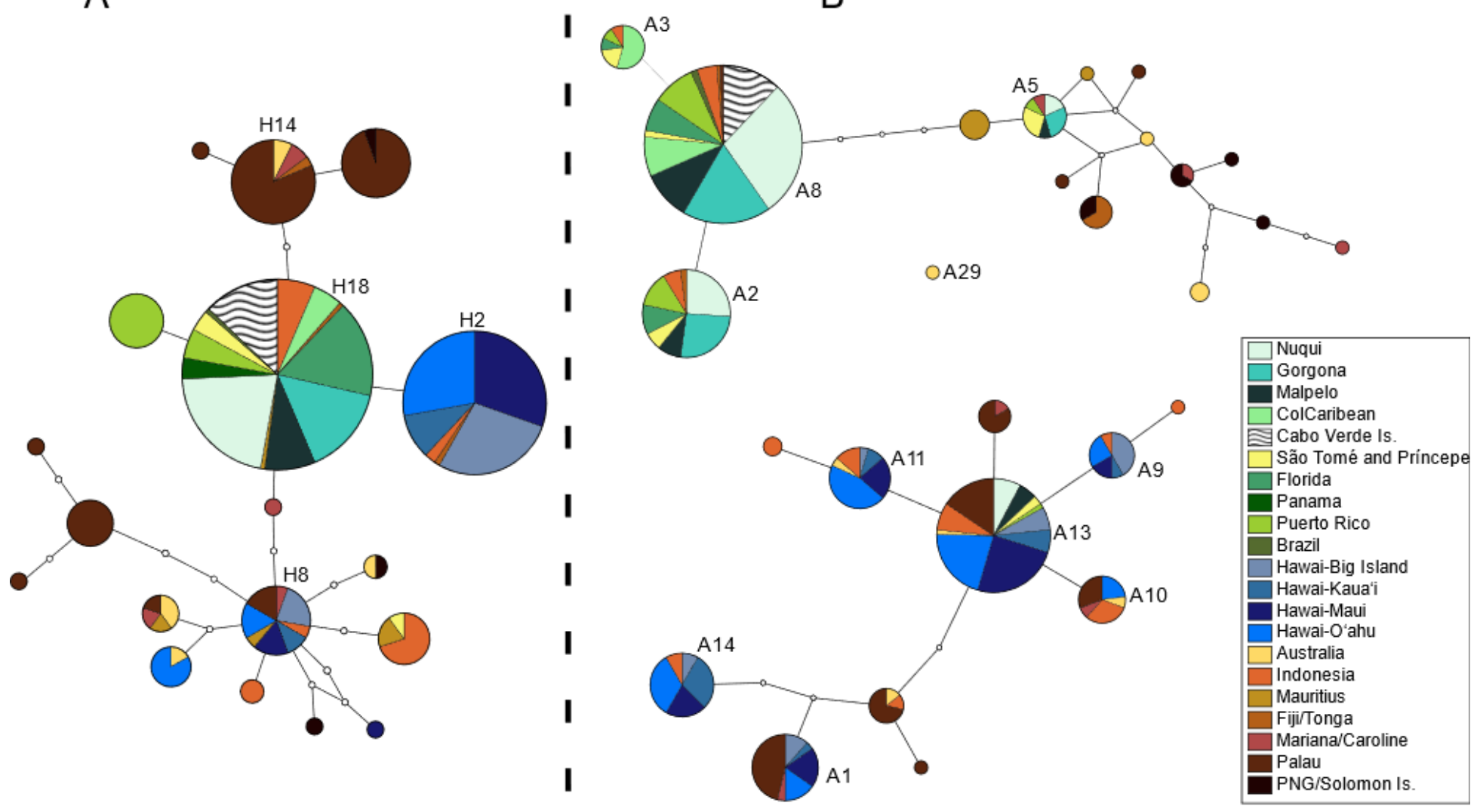

Figure 2

Phylogenetic networks of C. riisei based on mtDNA (A) and alleles of the nDNA (B) from the alignment of the $C$. riisei samples from Cabo Verde compared with the data in Genbank. The size of each circle indicates relative abundance in the data set. Primary colours were used in Hawai'i (blue), Atlantic/Pacific (green) and Indo-Pacific (red), and intermediate shades for each site where the specimens were recorded. Haplotype labels were based on Quintanilla et al. (2017

\section{Supplementary Files}

This is a list of supplementary files associated with this preprint. Click to download.

- Table1.xlsx

- Tables1.xIsx

- TableS2.xlsx

- TableS3.xIsx 